\title{
Microbial Activity Balance in Size Fractionated Suspended Growth Biomass from Full-scale Sidestream Combined Nitritation-Anammox Reactors
}

\author{
Yijing Shi ${ }^{1,2}$, George Wells ${ }^{1,3, *}$, Eberhard Morgenroth ${ }^{1,4}$ \\ ${ }^{1}$ Eawag, Swiss Federal Institute of Aquatic Science and Technology, Ueberlandstr. 133, 8600 \\ Duebendorf, Switzerland \\ ${ }^{2}$ Shandong Provincial Key Laboratory of Water Pollution Control and Resource Reuse, School \\ of Environmental Science and Engineering, Shandong University, Jinan 250100, China \\ ${ }^{3}$ Northwestern University, Department of Civil and Environmental Engineering, Evanston, IL, \\ USA \\ ${ }^{4}$ ETH Zurich, Institute of Environmental Engineering, 8093 Zurich, Switzerland
}

* Corresponding author: George Wells, telephone: +1 847491 8794; e-mail:

george.wells@northwestern.edu

(C) 2016. This manuscript version is made available under the Elsevier user license 


\section{Abstract}

The purpose of this study is to determine the abundance, distribution and activity of aerobic ammonia-oxidizing bacteria (AOB) and anammox in size fractioned aggregates from full-scale suspended growth combined nitritation-anammox sidestream reactors. Plants with or without a cyclone device were also studied to assess a purported enrichment of anammox granules. Specific aerobic ammonium oxidation rates $(\mathrm{p}=0.01)$ and specific oxygen uptake rates $(\mathrm{p}=0.02)$ were significantly greater in flocs than in granules. AOB abundance measured using quantitative FISH was significantly higher in flocs than in granules $(\mathrm{p}=0.01)$. Conversely, anammox abundance was significantly greater in granules $(\mathrm{p}=0.03)$. The average ratio of anammox/AOB in systems employing hydrocyclone separation devices was 2.4 , significantly higher $(\mathrm{p}=0.02)$ than the average ratio (0.5) in a system without a hydrocyclone. Our results demonstrate substantial functional and population-level segregation between floccular and granular fractions, and provide a key corroboration that cyclone separation devices can increase anammox levels in such systems.

Keywords: granular sludge; flocs; anammox; AOB; hydrocyclone

\section{Introduction}

Single-stage combined nitritation-anammox processes select for both partial nitritation and anammox in the same reactor. Such processes are dependent upon the balanced activity and interactions of both aerobic ammonia-oxidizing bacteria (AOB) and anaerobic ammoniaoxidizing bacteria (anammox), which have been confirmed as an attractive option for nitrogen removal in high-strength wastewater due to low operational costs and energy consumption (Kartal et al., 2010). In the last few years, this process has evolved from lab reactors to full-scale wastewater treatment plants (Christensson et al., 2013; Joss et al., 2009). However, process 
instabilities and extended start-up periods have slowed widespread implementation of this promising technology (Joss et al., 2011). Increased knowledge of distribution and activity of microbial populations in combined nitritation-anammox biomass may assist in overcoming these barriers. The present study advances our understanding of the role of different microbial aggregates in combined nitritation-anammox processes.

Microbial aggregates in wastewater treatment systems are often in the form of loosely structured flocs, or dense granules. Granules are compact aggregates that do not flocculate under reduced hydrodynamic shear, have an approximately spherical shape, and settle significantly faster than flocs (Lemaire et al., 2008). In selected common unit processes at wastewater treatment plants (WWTPs), flocs and larger aggregates commonly coexist (Carvalho et al., 2006; Innerebner et al., 2007). Recent studies suggest that small and large aggregates may play different functional roles in the systems, particularly in granular nitritation-anammox processes (Gilbert et al., 2013; Hubaux et al., 2015; Vlaeminck et al., 2008; Volcke et al., 2010). (Vlaeminck et al., 2010) demonstrated that the rate of activity and abundance of anammox increased with increasing aggregate size in biomass obtained from three combined nitritationanammox reactors. Two of the reactors were composed primarily of large $(>1 \mathrm{~mm})$ dense granules and all of them contained a significantly higher fraction of granules than those assessed in this study. These results suggest that distribution of aggregate size and types may be important for successful nitrogen removal in full-scale suspended growth combined nitritation-anammox reactors. Thus far, however, our knowledge of microbial activity and population segregation in such suspended growth reactors is lacking.

Enhanced biomass retention in combined nitritation-anammox reactors is a considerable advantage, considering the slow growth rate of anammox. Hydrocyclone separation units are 
purported to be a good choice for effective retention of anammox-laden biomass, and such cyclones have recently seen deployment in the DEamMONification (DEMON) process, a suspended growth combined nitritation-anammox process (Klein et al., 2013; Lackner et al., 2014). Activity tests and modeling work indicate a doubling of anammox/AOB mass ratio in reactors with such cyclones (Wett et al., 2010b). However, to date no direct quantification of microbial populations in systems with and without hydrocyclones has verified this result.

In this study, several full-scale sidestream combined nitritation-anammox reactors with or without hydrocyclones for enhanced biomass separation were selected to assess the distribution and ratio of $\mathrm{AOB}$ and anammox in different microbial aggregates using quantitative fluorescence in situ hybridization (FISH) technology. Furthermore, the activity of AOB and anammox were also investigated in batch aerobic and anoxic assays. The specific objectives of this study were twofold: 1) to characterize population and activity segregation between aggregate fractions in biomass from full-scale suspended growth combined nitritation-anammox reactors; and 2) to quantitatively assess via molecular tools the increased retention of anammox biomass in systems employing hydrocylone separators.

\section{Materials and methods}

\subsection{Full-scale combined nitritation-anammox biomass}

Representative mixed liquor samples were obtained from three full-scale combined nitritation-anammox reactors treating anaerobic digester supernatant: Werdhölzli WWTP (Zürich, Switzerland), Limmattal WWTP (Zürich, Switzerland) and ARA Thunersee WWTP (Thun, Switzerland). An overview of typical operating conditions for these plants is provided in Table 1. Both Limmattal and Thunersee reactors are operated with hydrocyclones intended to enrich 
granules. Hydrocyclones make use of centrifugal forces to select appropriate solids retention time (SRT) and retain denser microbial aggregates in the system (Wett et al., 2010a). The waste activated sludge is fed to a hydrocyclone from where the overflow containing floccular biomass is wasted and the underflow enriched in granules is recycled to the reactor (Nyhuis, 2013; Wett et al., 2013). Werdhölzli is operated as a sequencing batch reactor (SBR). Samples taken at different time points are referred to herein as Werd1 (Werdhölzli WWTP; April 25, 2012), Werd2 (Werdhölzli WWTP; October 5, 2012), Limma (Limmattal WWTP; May 8, 2012) and Thun (Thunersee WWTP, October 4, 2012). After sampling from the plant, the biomass was immediately separated into two fractions using a sieve with $0.5 \mathrm{~mm}$ pore size, and then washed with deionized water to remove residual dissolved reactor compounds. Samples were fixed immediately for quantitative FISH. Unfixed samples were stored temporarily at $4{ }^{\circ} \mathrm{C}$ prior to series of activity experiments (less than one week).

\subsection{Aerobic and anoxic batch activity experiments}

Aerobic and anoxic batch experiments were carried out to examine AOB and anammox activities. Both assays were adapted from the methodology employed by (Vlaeminck et al., 2007). Digester supernatant collected from the Werdhölzli WWTP was used for activity tests. The supernatant composition is as follows: $\mathrm{pH} 8.3 \pm 0.2, \mathrm{NH}_{4}{ }^{+}-\mathrm{N} 750 \pm 25 \mathrm{mg} / \mathrm{L}, \mathrm{NO}_{2}{ }^{-}-\mathrm{N}<0.5$ $\mathrm{mg} / \mathrm{L}, \mathrm{NO}_{3}{ }^{-} \mathrm{N} 2 \pm 1 \mathrm{mg} / \mathrm{L}, \mathrm{COD} 450 \pm 50 \mathrm{mg} / \mathrm{L}$. For the aerobic activity tests, biomass (a final VSS (volatile suspended solids) of around $2 \mathrm{~g} / \mathrm{L}$ ) was incubated in $250 \mathrm{~mL}$ Erlenmeyer flasks at $28{ }^{\circ} \mathrm{C}$, with ammonium (using diluted digester supernatant, with a final $\mathrm{NH}_{4}{ }^{+}-\mathrm{N}$ concentration of $100 \mathrm{mg} / \mathrm{L}$ ) as the substrate. A buffering solution (final concentrations $1 \mathrm{~g} \mathrm{NaHCO} / \mathrm{L}, 3.4 \mathrm{~g}$ $\mathrm{KH}_{2} \mathrm{PO}_{4} / \mathrm{L}$ and $4.4 \mathrm{~g} \mathrm{~K}_{2} \mathrm{HPO}_{4} / \mathrm{L}$ ) was also added. Gastight anoxic serum vials $(150 \mathrm{~mL})$ were 
used in the anoxic batch experiments at $32^{\circ} \mathrm{C}$, with ammonium (diluted digester supernatant, with a final $\mathrm{NH}_{4}{ }^{+}-\mathrm{N}$ concentration of $100 \mathrm{mg} / \mathrm{L}$ ) and nitrite (sodium nitrite, with a final $\mathrm{NO}_{2}^{-}-\mathrm{N}$ concentration of $100 \mathrm{mg} / \mathrm{L}$ ) as substrates; a buffering solution was also added (final concentrations $1 \mathrm{~g} \mathrm{NaHCO}_{3} / \mathrm{L}$ and $0.04 \mathrm{~g} \mathrm{KH}_{2} \mathrm{PO}_{4} / \mathrm{L}$ ). The serum vials were sealed with rubber stoppers and flushed with $\mathrm{N}_{2}$ gas for 30 min to obtain anoxic conditions. During incubation, liquid samples were taken over time and used for ammonium, nitrite, and nitrate analyses. The mixed liquor volatile suspended solid (MLVSS) was also analyzed to assess the activity per unit biomass. Aerobic activity assays were performed in triplicate, and anoxic activity assays were performed in duplicate. The corresponding experimental conditions are shown in Table S1. Specific oxygen utilization rates (SOUR) were determined using methods previously described by (Liu et al., 2004), with diluted anaerobic digester supernatant containing substrates of 100 $\mathrm{mg} / \mathrm{L} \mathrm{NH}_{4}{ }^{+}-\mathrm{N}$ and around $60 \mathrm{mg} / \mathrm{L} \mathrm{COD}$. Diluted supernatant and pre-aerated sludge were mixed in a biochemical oxygen demand (BOD) bottle. The DO (dissolved oxygen) reading was started immediately and lasted for at least 20 min or until DO concentration was less than $1 \mathrm{mg} / \mathrm{L}$. The oxygen utilization rate (OUR) was obtained from the slope of the linear portion of the DO versus time curve and then the SOUR was calculated by dividing the OUR by the VSS concentration (Henriques \& Love, 2007).

\subsection{FISH}

Fluorescence in-situ hybridization (FISH) was used to visualize the distribution of AOB, NOB (nitrite-oxidizing bacteria) and anammox and to quantitatively assess AOB and anammox abundance in different fractioned biomass. After sieving, sludge samples were immediately fixed at $4{ }^{\circ} \mathrm{C}$ for $1.5 \mathrm{~h}$, by adding $37 \%(\mathrm{v} / \mathrm{v})$ stabilized formaldehyde (FA) (Sigma Aldrich, Germany), 
with a final FA concentration of $4 \%$. Samples were then washed three times using phosphatebuffered saline solution (PBS, $\mathrm{pH}$ 7.2) and resuspended in 1:1 (v/v) mixture of ethanol/PBS. For quantification, fixed biomass was homogenized to a fine amorphous paste with a mortar and pestle (Daffonchio et al., 1995). To visualize the microbial structure, large aggregates were cut into $20 \mu \mathrm{m}$ slices with a cryomicrotome (Zeiss Hyrax C 60, Germany) and attached to poly-Llysine coated slides (SuperFrost Ultra Plus, Menzel-Gläser, Germany). Samples were stored at $20{ }^{\circ} \mathrm{C}$ for further analyses. FISH was performed as previously described (Joss et al., 2011; Nielsen et al., 2009). The 16S rRNA-targeted oligonucleotide probes are shown in Table S2. For visualization and quantification of biomass architecture and microbial population abundance, at least 15 randomly acquired fields of view were recorded by confocal laser scanning microscopy (CLSM) (Leica SP5, Germany). Images were analyzed using the colocalization function of the Leica LAS AF software. The relative abundances of AOB and Anammox were estimated by calculating the ratio of their specific bacterial biovolume to the total bacterial biovolume. The ratio of Anammox to AOB abundance was calculated using the relative abundances of Anammox and AOB (results shown in Table 2).

\subsection{Particle size and morphological analysis}

Particle size distributions for total biomass, floccular biomass, and granular biomass were measured by a laser particle size analysis system (Master size 2000, Malvern, Britain). Every sample was measured in triplicate. The biomass morphology was imaged using a stereomicroscope (Olympus szx10, Japan). 


\subsection{Chemical and statistical analyses}

Liquid samples were filtered through a $0.45 \mu \mathrm{m}$ syringe filter (Chromafil Membranfilter, Macherey-Nagel, Germany) and stored at $4{ }^{\circ} \mathrm{C}$ before measurement. $\mathrm{NH}_{4}{ }^{+}-\mathrm{N}$ was analyzed by spectrophotometry in a flow injection system (FIAstar 5000 analyzer, Foss, Denmark). $\mathrm{NO}_{3}{ }^{-} \mathrm{N}$ and $\mathrm{NO}_{2}-\mathrm{N}$ were determined by anion chromatography (881 compact IC, Metrohm). Commercial colorimetric test kits (Hach Lange GmbH, Düsseldorf, Germany) were used to measure COD (LCK 314, LCK 414, or LCK 114). MLSS (mixed liquor suspended solid) and VSS contents were determined using standard methods (APHA, 2005). pH was measured potentiometrically, and the DO concentration and water temperature were monitored with a DO meter (Oxi 340, WTW, Germany). Significance testing using Student's t-test (2 tailed t-test) was applied for data comparison.

\section{Results}

\subsection{Aggregate size distribution}

The impetus for this study arose from the observation of the coexistence of distinct large, dense pink or reddish granules and small, brownish flocs in suspended growth biomass from the full-scale combined nitritation-anammox reactors at the Zürich Werdhölzli WWTP (herein abbreviated as Werd 1 and Werd2, indicating 2 time points of sampling); Limmattal WWTP (herein abbreviated as Limma); and Thunersee WWTP (herein abbreviated as Thun). Representative stereomicroscope images of flocs and granules in biomass from Werd1 are shown in Fig. S1 A and B. These observations parallel those previously noted in literature (Fux, 2003; Innerebner et al., 2007). For the purposes of this study, we define the granular fraction (granules) as aggregates with a diameter larger than $0.5 \mathrm{~mm}$, and the floccular fraction (flocs) as aggregates 
smaller than $0.5 \mathrm{~mm}$. In fact, the floccular fraction was predominantly flocs, but also included some small pinkish dense aggregates $(<0.5 \mathrm{~mm})$, while the larger granule fraction was exclusively composed of dense aggregates.

We employed a laser light scattering technique to characterize the particle size distribution of biomass in the reactors under investigation (Fig. 1). In all cases (especially for Limma and Thun), a bimodal distribution of aggregate sizes was apparent, with a putative floccular fraction present at $<100 \mu \mathrm{m}$ and a putative granular fraction present at around $500 \mu \mathrm{m}$. In order to study these two typical fractions separately, sieves with a pore size of $0.5 \mathrm{~mm}$ were used to physically separate the biomass into two fractions: flocs $(<0.5 \mathrm{~mm})$ and granules $(\geq 0.5 \mathrm{~mm})$. For Werd 1 and Werd2, the particle size distribution of floccular biomass was nearly identical to the combined biomass, demonstrating that only a small fraction of granules existed in the system (Fig. 1). This was further confirmed by testing the mass percentage of granules in the combined sludge using VSS tests: granules (i.e. $\geq 0.5 \mathrm{~mm}$ ) accounted for only $2.5 \%$ and $3.4 \%$ of total VSS in Werd1 and Werd2 suspended growth, respectively (Table 2). Despite their small mass fraction, the granules exhibited substantially larger diameters than the combined or floccular biomass, with a volume weighted mean of $767 \pm 10 \mu \mathrm{m}$ and $703 \pm 20 \mu \mathrm{m}$ in Werd 1 and Werd2, respectively. Thun suspended growth had the highest granule mass percent (11.2\% VSS) among all the samples tested in this study, while Limma suspended growth also had a high granule percent (5.7 \% VSS). The mean diameter of the granules (volume weighted mean) was $592 \pm 6 \mu \mathrm{m}$ and $536 \pm 4 \mu \mathrm{m}$ for Thun and Limma systems, respectively. Both Limma and Thun were equipped with hydrocyclone to separate granular biomass from flocs and effluent. 


\subsection{Aggregate architecture and microbial distribution}

\subsubsection{Aggregate architecture}

The appearance of aggregates was different in the three different systems examined. In Werdhölzli system (Werd1 and Werd2), almost all the flocs were brownish, with some granules brownish and the others red (Fig. S1 A and B). However, for Limma and Thun, some small red aggregates also existed in the flocs fraction and almost all the larger granules were red.

\subsubsection{Microbial distribution}

We employed biomass prior to sieving (referred to as "combined" biomass) from all plants to visualize the distribution of $\mathrm{AOB}, \mathrm{NOB}$ and anammox and assess relative abundances of $\mathrm{AOB}$ and anammox via FISH. Almost no NOB were observed in Werd1 and Werd 2 suspended growth and a few NOB $(<1 \%)$ were found in Limma and Thun suspended growth in CLSM micrographs. Clear clusters for AOB and anammox were apparent in all the samples (Fig. S1). Results in Table 2 for AOB and anammox abundance revealed that the ratio of anammox/AOB was significantly higher $(\mathrm{p}=0.02)$ in Limma and Thun (with hydrocyclone separation units) than in Werd1 and Werd2 (no hydrocyclone separation unit). The anammox/AOB ratio in Limma and Thun averaged 2.4, while the average ratio was around 0.5 in samples from Werd.

\subsubsection{Microbial distribution in granular and floccular fractions}

Representative granules from all three systems were cryosectioned and then hybridized in order to qualitatively assess the microbial distribution and morphology in the granules with FISH

(Fig. S1 D, E, and F). A thin layer of AOB can be seen in the outer edge of the granule, while a large amount of anammox existed inside the granule. AOB and anammox abundance was 
quantified in the separated floccular and granular fractions from each reactor (Table 2). Results revealed substantial segregation in microbial population structure between aggregate fractions. AOB abundance in all biomass samples was significantly elevated in the floccular fraction relative to the granular fraction $(\mathrm{p}=0.01)$, while anammox was significantly more abundant in the granular fraction $(\mathrm{p}=0.03)$.

\subsection{Aggregate activity analysis}

In combined nitritation-anammox suspended growth processes, AOB play an important role to oxidize ammonium to nitrite under aerobic conditions, while anammox convert nitrite and ammonium to nitrogen gas under anoxic conditions. To assess spatial segregation of microbial activities in such systems, we therefore determined activities of AOB and anammox under aerobic (Fig. 2) and anoxic (Fig. 3) conditions, respectively, in combined, floccular and granular biomass fractions.

\subsubsection{Biomass activity of combined nitritation-anammox suspended growth}

Combined sludge (prior to fractionation) from three plants sampled at four different time points (Werd1, Werd2, Limma and Thun) showed variable activities under anoxic and aerobic conditions (Table 2). In summary, Werd1 showed the highest aerobic ammonium consumption rate of $476 \pm 22 \mathrm{mgN} /(\mathrm{gVSS}$ day), which represented the highest AOB activity, while Limma had the lowest aerobic ammonium consumption rate $(188 \pm 13 \mathrm{mgN} /(\mathrm{gVSS}$ day $))$. Thun showed the

highest anoxic ammonium consumption rate of $96 \pm 21 \mathrm{mgN} \mathrm{g}^{-1} \mathrm{VSS}$ day $^{-1}$, representing the highest anammox activity, while Werd 2 had the lowest anoxic ammonium consumption rate (34 $\pm 1 \mathrm{mgN} /(\mathrm{gVSS}$ day)). Results indicate that Limma showed a comparatively low AOB activity 
and Werd 2 showed a low anammox activity. Interestingly, while rates of $\mathrm{NO}_{3}{ }^{-} \mathrm{N}$ production in Werd 1 and Werd 2 under aerobic conditions were essentially negligible, $65 \pm 1$ and $18 \pm 0 \mathrm{mg} \mathrm{NO}_{3}{ }^{-}-$ $\mathrm{N} /(\mathrm{gVSS}$ day) were produced in aerobic batch assays with Limma and Thun biomass, respectively. The higher $\mathrm{NO}_{3}{ }^{-} \mathrm{N}$ production rates in Limma and Thun indicate elevated NOB activity relative to Werd 1 and Werd2.

\subsubsection{Biomass activity in size fractionated suspended growth}

Our data showed that under aerobic conditions, both flocs and granules could consume ammonium, but in all cases tested, aerobic ammonium oxidation activity was significantly higher in the floccular fraction than in granules $(\mathrm{p}=0.01)$ (Fig. 2, Table 2). Ammonium consumption rates varied substantially within both biomass fractions. In the floccular fraction, consumption rates varied between $188 \pm 5 \mathrm{mg} \mathrm{NH}_{4}{ }^{+}-\mathrm{N} /\left(\mathrm{gVSS}\right.$ day) in Limma to $448 \pm 11 \mathrm{mg} \mathrm{NH}_{4}{ }^{+}-\mathrm{N} /(\mathrm{gVSS}$ day) in Werd1, while in the granular fraction rates varied between $25 \pm 25 \mathrm{mg} \mathrm{NH}_{4}{ }^{+} \mathrm{N} /(\mathrm{gVSS}$ day $)$ in Werd2 to $196 \pm 17 \mathrm{mg} \mathrm{NH}_{4}{ }^{+}-\mathrm{N} /(\mathrm{gVSS}$ day) in Thun. Results clearly demonstrate substantial segregation of AOB activity between flocs and granules. The primary product of aerobic ammonia consumption was nitrite, with very low $(<3 \mathrm{mgN} / \mathrm{L})$ observed production of nitrate in Werd 1 Werd 2 and Thun samples, with the exception of Limma. Higher levels of nitrate than nitrite were found in Limma aerobic batch experiments, demonstrating high activity of NOB compared to other systems. To evaluate the aerobic nitrite accumulation potential of the aggregates, the nitrite accumulation ratio (NAR) was calculated by dividing the net nitrite production rate by the sum of nitrite and nitrate production rates. Data showed low NAR both in floccular and granular fractions of Limma samples. The NAR levels of Thun were substantially higher than that of Limma, but slightly lower than Werd1 and Werd2. 
To assess anammox activity in biomass fractions, we subjected samples from Werd2, Limma and Thun to anoxic batch activity tests at $32^{\circ} \mathrm{C}$ (Fig. 3, Table 2). In all cases, rates of ammonium consumption under anoxic conditions were higher in granules than flocs. These results corroborate the observed segregation of activity between aggregate fractions in aerobic batch experiments, and demonstrate enhanced anammox activity in granules relative to floccular biomass. In the floccular fraction, ammonium consumption rates varied between $28 \pm 11 \mathrm{mg}$ $\mathrm{NH}_{4}{ }^{+}-\mathrm{N} /\left(\mathrm{gVSS}\right.$ day) in Werd 2 to $95 \pm 9 \mathrm{mg} \mathrm{NH}_{4}{ }^{+}-\mathrm{N} /(\mathrm{gVSS}$ day) in Thun, while in the granular fraction rates varied between $34 \pm 2$ in Werd 2 to $120 \pm 1 \mathrm{mg} \mathrm{NH}_{4}{ }^{+} \mathrm{N} /(\mathrm{gVSS}$ day) in Limma.

\subsubsection{Biomass activity based on SOUR test}

SOUR is another indicator of microbial activity under aerobic conditions. When using ammonium as substrate, SOUR tests show the joint oxygen utilization rates for both AOB and NOB. When COD is the substrate, it indicates the oxygen utilization rate of heterotrophic bacteria (HB). In the present study, the diluted sludge digested supernatant contained $\mathrm{NH}_{4}{ }^{+}-\mathrm{N}$ $(100 \mathrm{mg} / \mathrm{L})$ and $\mathrm{COD}(60 \mathrm{mg} / \mathrm{L})$. Both $\mathrm{NO}_{2}{ }^{-} \mathrm{N}$ and $\mathrm{NO}_{3}{ }^{-} \mathrm{N}$ could be ignored due to their low concentrations $(<0.2 \mathrm{mg} / \mathrm{L})$. SOUR tests hence showed oxygen utilization rates for aerobic bacteria (i.e. $\mathrm{AOB}, \mathrm{NOB}$ and $\mathrm{HB}$ ) in our study. Comparing the combined sludge, Thun showed the highest oxygen utilization rate of $72.8 \mathrm{mgO}_{2} / \mathrm{g} \mathrm{VSS} / \mathrm{h}$, while Limma had the lowest rate of $9.1 \mathrm{mgO}_{2} / \mathrm{g} \mathrm{VSS} / \mathrm{h}$ (Fig. 4). Considering the floccular and granular fractions, data show a quite similar phenomenon as that in aerobic batch ammonium consumption activity tests. For all the samples, floccular fractions had significantly higher oxygen utilization rates (53.9, 32.1, 9.8 and $72.4 \mathrm{mgO}_{2} / \mathrm{g} \mathrm{VSS} / \mathrm{h}$, respectively) than granular fractions $\left(5.4,4.8,1.4\right.$ and $20.1 \mathrm{mgO}_{2} / \mathrm{g} \mathrm{VSS} / \mathrm{h}$, respectively) ( $\mathrm{p}=0.02)$, indicating enrichment of $\mathrm{AOB}, \mathrm{NOB}$ and $\mathrm{HB}$ in the former. 


\section{Discussion}

\subsection{Balance of microbial and activity distribution in size fractionized aggregates}

The first objective of this study was to determine the balance of microbial population and activity distribution in aggregate fractions from different full-scale combined nitritationanammox systems. The biomass samples examined in this study had various aerobic (ranging from $188 \pm 13$ to $476 \pm 22 \mathrm{mg} \mathrm{NH}{ }_{4}{ }^{+} \mathrm{N} /(\mathrm{gVSS}$ day)) and anoxic activities (ranging from $34 \pm 1$ to $96 \pm 21 \mathrm{mg} \mathrm{NH}_{4}{ }^{+}-\mathrm{N} /(\mathrm{gVSS}$ day)). However, in all samples the abundance of AOB was significantly higher in the floccular fractions, leading to a higher aerobic activity, while the abundance and activity of anammox were higher in the granular fractions. In suspended growth combined nitritation-anammox processes, previous studies (Fux et al., 2002; Innerebner et al., 2007) also noted a clear distinction between multiple biomass fractions — namely, loose floccular material and dense, red or brownish granules — despite lack of conditions such as short settling times or high shear stress often associated with granule production. Innerebner and colleagues (2007) demonstrated a substantial variation in overall microbial community structure between such floccular and granular fractions in a combined nitritation-anammox reactor without a hydrocyclone, but did not quantify microbial population segregation. Vlaeminck et al. (2010) demonstrated size-associated population and activity segregation in predominantly granular OLAND (oxygen limited autotrophic nitrification denitrification) reactors. However, such an assessment has not been performed in primarily floccular systems at the full-scale. Moreover, a comparison of population and activity segregation between aggregate fractions (flocs and granules) in plants with and without hydrocyclone units has to date not been performed. In all cases examined here, our results indicate a significant and substantial elevation of activity and 
abundance of AOB in floccular biomass (flocs), while the abundance and activity of anammox were higher all granular fractions.

Segregation of activities and populations between aggregate fractions (flocs and granules) has been observed in other unrelated systems. (Carvalho et al., 2006) noted an approximately equal volume-based distribution of flocs $(<300$ um) and granules (>300 um) in a nitrifying/denitrifying SBR, with NOB and AOB concentrated in granules and flocs, respectively. They further speculated that this segregation of populations may be related to the fast growth rate of $\mathrm{AOB}$ relative to NOB. Other researchers have also noted that, in hybrid systems, the community structure varies substantially between floccular and biofilm phases (Kwon et al., 2010), with faster growing microbial populations tending to grow in suspension and slower growing populations predominant in the biofilm (Chung et al., 2007; Ochoa et al., 2002; van Benthum et al., 1997). Combined nitritation-anammox systems rely on coexistence of (relatively fast growing) $\mathrm{AOB}$ and slow-growing anammox, and it is thus feasible that the observed population segregation between flocs and granules in this study is related to growth rates of the key microbial players.

It is also likely, however, that this segregation is related to the aerobic and anoxic metabolisms of AOB and anammox, respectively. Granular sludge can be regarded as a type of biofilm and is a self-immobilized community of bacteria (Liu \& Tay, 2002). It is likely that floccular material is exposed directly to bulk oxygen conditions while granular biofilm material is in at least some cases oxygen-limited, and this may provide an additional selection pressure for segregation of microbial populations. Indeed, Hubaux and colleagues (2015) modeled population distributions in biomass from granular nitritation-anammox reactors with small fractions ( $5 \%$ VSS) of floccular material, and detailed strong patterns of spatial microbial organization, with 
$\mathrm{AOB}$ and heterotrophs dominating both the surface of granules and the floccular material and anammox dominating the majority of granular biomass. Further delineation of the causes of activity and population segregation observed in our study will require characterization of variations in mass transfer limitations, oxygen distribution, and micro-scale activity measurements in flocs and granules under in-situ conditions.

\subsection{Microbial and activity distribution in systems with or without hydrocyclones}

The second objective of this study was to quantitatively assess via molecular tools the increased retention (abundance) of anammox biomass in combined nitritation-anammox systems employing hydrocyclone separators. In this study, two systems (Limma and Thun) using hydrocyclones for enhanced granule retention were chosen, and one system at multiple time points (Werd1 and Werd2) without a hydrocyclone was used for comparison.

Hydrocyclones are commonly employed in a wide variety of applications to separate particulates from liquid at high throughput; past applications in wastewater treatment include separation of fly ash absorbent (Rastogi et al., 2008), struvite precipitates (Kern et al., 2008), or sand (Krupp et al., 2005) from the water phase. The hypothesis behind hydrocyclone use in combined nitritation-anammox systems is that dense granules maintain higher anammox populations and activities then less dense flocs in suspended growth nitritation-anammox systems, while the floccular fraction maintains elevated AOB population and activities (Daigger

et al., 2011). However, quantitative validation of an increase in anammox abundance relative to AOB in systems employing a hydrocyclone has to date been lacking.

Our results addressed this knowledge gap by clearly demonstrating via quantitative FISH a strong and significant increase in anammox/AOB ratios in plants employing hydrocyclones 
relative to those without this technology. Anammox/AOB ratios were 2.08 for Limma and 2.68 for Thun, both of which were equipped with hydrocyclones, compared to 0.52 for Werd 1 and 0.45 for Werd2. This result was in line with the activity tests and modeling results reported by (Wett et al., 2010b), in which almost a doubling of the ratio of anammox activity to AOB in the system was reported. Moreover, Limma and Thun were found to harbor higher VSS percentage of granular biomass (5.7\% and $11.2 \%$ separately) compared with Werd1 and Werd2 systems, demonstrating that hydrocylones are effective concentrators of granules in combined nitritationanammox systems. It should be emphasized, however, that granules were also present in the system without a hydrocyclone, indicating that hydrocyclones influence the extent but not the presence or absence of granular aggregates in suspended growth nitritation-anammox reactors.

Taken together, our results indicate substantial activity and population segregation between floccular and granular biomass fractions in suspended growth nitritation-anammox systems, thus providing a key experimental justification for the use of enhanced biomass separation techniques such as hydrocyclones as a means of separating the SRT of these two fractions. In addition, our results provide quantification of microbial populations to directly demonstrate the effectiveness of hydrocyclones in also elevating the ratio of anammox/AOB in such systems.

\section{Conclusions}

Substantial segregation in microbial populations and activity was observed between flocs and granules in systems with and without hydrocyclones. Different aggregate fractions (flocs and granules) each play unique and critical roles in enabling growth and activity of key microbial populations in suspended growth combined nitritation-anammox reactors. AOB abundance and activity was higher in the floccular fractions, while anammox activity and abundance was 
elevated in the granular fractions. The anammox/AOB ratio was significantly elevated in biomass from plants employing hydrocyclones, validating the effectiveness of such separation devices in retaining slow-growing anammox biomass.

\section{Acknowledgements}

This work was financially supported by the State-Sponsored Scholarship Program from the China Scholarship Council. G. W. was supported by the US National Science Foundation under IRFP Grant No. 1064615 and by an Eawag Postdoctoral Fellowship.

\section{Supplementary data}

Additional information about Fluorescence in-situ hybridization (FISH), overview of the activity test conditions, Oligonucleotide probes applied for fluorescence in situ hybridization (FISH) and micrographs of biomass from three systems can be found in the supporting information. 


\section{References}

APHA. 2005. Standard methods for the examination of water and wastewater. American Public Health Association (APHA): Washington, DC, USA.

Carvalho, G., Meyer, R.L., Yuan, Z., Keller, J. 2006. Differential distribution of ammonia-and nitrite-oxidising bacteria in flocs and granules from a nitrifying/denitrifying sequencing batch reactor. Enzyme Microb. Technol., 39(7), 1392-1398.

Christensson, M., Ekström, S., Chan, A.A., Le Vaillant, E., Lemaire, R. 2013. Experience from start-ups of the first anita mox plants. Water Sci. Technol., 67(12), 2677-2684.

Chung, J., Bae, W., Lee, Y.-W., Rittmann, B.E. 2007. Shortcut biological nitrogen removal in hybrid biofilm/suspended growth reactors. Process Biochemistry, 42(3), 320-328.

Daffonchio, D., Thaveesri, J., Verstraete, W. 1995. Contact angle measurement and cell hydrophobicity of granular sludge from upflow anaerobic sludge bed reactors. Appl. Environ. Microbiol., 61(10), 3676-3680.

Daigger, G.T., Sanjines, P., Pallansch, K., Sizemore, J., Wett, B. 2011. Implementation of a fullscale anammox-based facility to treat an anaerobic digestion sidestream at the Alexandria sanitation authority water resource facility. Water Practice \& Technology, 6(2).

Fux, C. 2003. Biological nitrogen elimination of ammonium-rich sludge digester liquids, Diss., Technische Wissenschaften ETH Zürich, Nr. 15018, 2003.

Fux, C., Boehler, M., Huber, P., Brunner, I., Siegrist, H. 2002. Biological treatment of ammonium-rich wastewater by partial nitritation and subsequent anaerobic ammonium oxidation (anammox) in a pilot plant. Journal of biotechnology, 99(3), 295-306. 
Gilbert, E.M., Müller, E., Horn, H., Lackner, S. 2013. Microbial activity of suspended biomass from a nitritation-anammox SBR in dependence of operational condition and size fraction. Applied microbiology and biotechnology, 97(19), 8795-8804.

Henriques, I.D., Love, N.G. 2007. The role of extracellular polymeric substances in the toxicity response of activated sludge bacteria to chemical toxins. Water Res., 41(18), 4177-4185.

Hubaux, N., Wells, G., Morgenroth, E. 2015. Impact of coexistence of flocs and biofilm on performance of combined nitritation-anammox granular sludge reactors. Water Research, 68(0), 127-139.

Innerebner, G., Insam, H., Franke-Whittle, I.H., Wett, B. 2007. Identification of anammox bacteria in a full-scale deammonification plant making use of anaerobic ammonia oxidation. Syst. Appl. Microbiol., 30(5), 408-412.

Joss, A., Derlon, N., Cyprien, C., Burger, S., Szivak, I., Traber, J., Siegrist, H., Morgenroth, E. 2011. Combined nitritation-anammox: advances in understanding process stability. Environ. Sci. Technol., 45(22), 9735-9742.

Joss, A., Salzgeber, D., Eugster, J., Konig, R., Rottermann, K., Burger, S., Fabijan, P., Leumann, S., Mohn, J., Siegrist, H. 2009. Full-Scale Nitrogen Removal from Digester Liquid with Partial Nitritation and Anammox in One SBR. Environ. Sci. Technol., 43(14), 5301-5306.

Kartal, B., Kuenen, J., Van Loosdrecht, M. 2010. Sewage treatment with anammox. Science, 328(5979), 702-703.

Kern, J., Heinzmann, B., Markus, B., Kaufmann, A.-C., Soethe, N., Engels, C. 2008. Recycling and assessment of struvite phosphorus from sewage sludge. Agricultural Engineering International: the CIGR Ejournal. 
Klein, A., Williams, L., Summers, A., Johnson, C., Melcer, H. 2013. Application of lessons learned during a pilot investigation to the full scale design of a DEMON® system to remove nitrogen from dewatering centrate. Proceedings of the Water Environment Federation, 2013(4), 350-364.

Krupp, M., Schubert, J., Widmann, R. 2005. Feasibility study for co-digestion of sewage sludge with OFMSW on two wastewater treatment plants in Germany. Waste Management, 25, 393-399.

Kwon, S., Kim, T.-S., Yu, G.-H., Jung, J.-H., Park, H.-D. 2010. Bacterial community composition and diversity of a full-scale integrated fixed-film activated sludge system as investigated by pyrosequencing. Journal of Microbiological Methods, 20(12), 1717-1723.

Lackner, S., Gilbert, E.M., Vlaeminck, S.E., Joss, A., Horn, H., van Loosdrecht, M.C. 2014. Fullscale partial nitritation/anammox experiences-an application survey. Water Res., 55, 292303.

Lemaire, R., Webb, R.I., Yuan, Z. 2008. Micro-scale observations of the structure of aerobic microbial granules used for the treatment of nutrient-rich industrial wastewater. ISME J., 2(5), 528-541.

Liu, Y., Tay, J.-H. 2002. The essential role of hydrodynamic shear force in the formation of biofilm and granular sludge. Water Res., 36(7), 1653-1665.

Liu, Y., Yang, S.-F., Tay, J.-H. 2004. Improved stability of aerobic granules by selecting slowgrowing nitrifying bacteria. J. Biotechnol., 108(2), 161-169.

Nielsen, P.H., Daims, H., Lemmer, H. 2009. FISH handbook for biological wastewater treatment: identification and quantification of microorganisms in activated sludge and biofilms by FISH. Iwa publishing. 
Nyhuis, G. 2013. Method and installation for treating wastewater containing ammonia, US Patent Application 14/085,841.

Ochoa, J.C., Colprim, J., Palacios, B., Paul, E., Chatellier, P. 2002. Active heterotrophic and autotrophic biomass distribution between fixed and suspended systems in a hybrid biological reactor. Water Science \& Technology, 46(1-2), 397-404.

Rastogi, K., Sahu, J.N., Meikap, B.C., Biswas, M.N. 2008. Removal of methylene blue from wastewater using fly ash as an adsorbent by hydrocyclone. Journal of Hazardous Materials, 158, 531-540.

van Benthum, W.A.J., van Loosdrecht, M.C.M., Heijnen, J.J. 1997. Process design for nitrogen removal using nitrifying biofilm and denitrifying suspended growth in a biofilm airlift suspension reactor. Water Science \& Technology, 36(1), 119-128.

Vlaeminck, S., Cloetens, L.F., Carballa, M., Boon, N., Verstraete, W. 2008. Granular biomass capable of partial nitritation and anammox. Water Sci. Technol., 58(5), 1113.

Vlaeminck, S.E., Geets, J., Vervaeren, H., Boon, N., Verstraete, W. 2007. Reactivation of aerobic and anaerobic ammonium oxidizers in OLAND biomass after long-term storage. Appl. Environ. Microbiol., 74(6), 1376-1384.

Vlaeminck, S.E., Terada, A., Smets, B.F., De Clippeleir, H., Schaubroeck, T., Bolca, S., Demeestere, L., Mast, J., Boon, N., Carballa, M., Verstraete, W. 2010. Aggregate Size and Architecture Determine Microbial Activity Balance for One-Stage Partial Nitritation and Anammox. Applied and Environmental Microbiology, 76(3), 900-909.

Volcke, E., Picioreanu, C., De Baets, B., van Loosdrecht, M. 2010. Effect of granule size on autotrophic nitrogen removal in a granular sludge reactor. Environ. Technol., 31(11), 12711280. 
Wett, B., Hell, M., Nyhuis, G., Puempel, T., Takacs, I., Murthy, S. 2010a. Syntrophy of aerobic and anaerobic ammonia oxidisers. Water Sci. Technol., 61(8), 1915.

Wett, B., Nyhuis, G., Podmirseg, S., Gómez-Brandón, M., Puempel, T., Hell, M., Kirchler, W., Cesconi, M., Murthy, S. 2013. Population dynamics at the limits of DEMON plant operations. $13^{\text {th }}$ World Congress on Anaerobic Digestion, Santiago de Compostela, Spain.

Wett, B., Nyhuis, G., Takács, I., Murthy, S. 2010b. Development of enhanced deammonification selector. Proceedings of the Water Environment Federation, 2010(10), 5917-5926. 


\section{List of Figures and Tables}

Fig. 1: Size distribution of suspended growth biomass from sidestream combined nitritationanammox reactors at the Zürich Werdhölzli WWTP (Werd1, and Werd2), the Limmattal WWTP (Limma), and the Thunersee WWTP as measured via laser light scattering by volume density distribution. Combined sludge indicates biomass prior to separation via sieving; Flocs indicates the small sieve fraction $(<0.5 \mathrm{~mm})$; and Granules indicates the sieve fraction with diameter larger than $0.5 \mathrm{~mm}$.

Fig. 2: Biomass specific ammonium consumption as well as nitrite and nitrate production during aerobic batch experiments ( $\square$ Combined sludge, $\bullet$ Flocs, and $\boldsymbol{\Delta}$ Granules). Error bars represent standard deviation at each time point for biological triplicates.

Fig. 3: Biomass specific ammonium and nitrite consumption during anoxic batch experiments, with nitrite as electron acceptor ( $\square$ Combined sludge, $\bullet$ Flocs, and $\boldsymbol{\Delta}$ Granules). Error bars represent standard deviation at each time point for biological duplicates.

Fig. 4: Biomass specific oxygen uptake rates (SOUR) for combined, floccular $(<0.5 \mathrm{~mm})$, and granular $(>0.5 \mathrm{~mm})$ fractions from full-scale nitritation-anammox reactors

Table 1: Overview of the three full-scale suspended growth combined nitritation-anammox reactors investigated in this study. Operational conditions represent typical values for each reactor, per communications with system operators. All systems are in Switzerland. 
Table 2: Activity and abundance of Anammox and AOB in different reactors and biomass fractions. $\mathrm{C}=$ combined biomass (prior to sieving), $\mathrm{F}=$ floccular biomass with diameter less than $0.5 \mathrm{~mm}$, and $\mathrm{G}=$ granular biomass with diameter higher than $0.5 \mathrm{~mm}$. Activity measurements are based on aerobic and anoxic batch experiments, and abundance data is based on quantitative FISH measurements. 

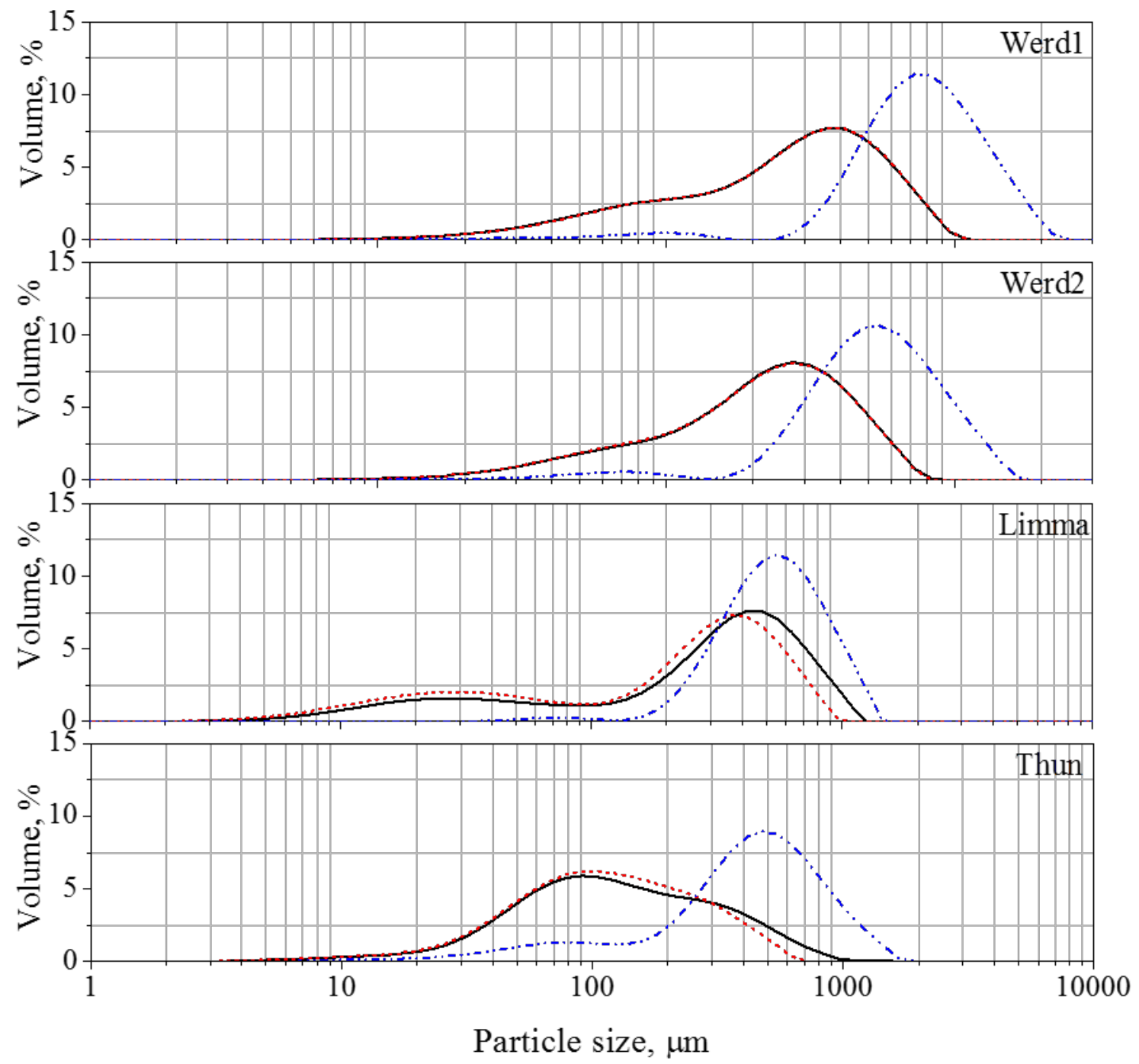

_Combined sludge ....... Flocs ...... Granules

Fig. 1 Size distribution of suspended growth biomass from sidestream combined nitritation-anammox reactors at the Zürich Werdhölzli WWTP (Werd1, and Werd2), the Limmattal WWTP (Limma), and the Thunersee WWTP as measured via laser light scattering by volume density distribution. Combined sludge indicates biomass prior to separation via sieving; Flocs indicates the small sieve fraction $(<0.5 \mathrm{~mm})$; and Granules indicates the sieve fraction with diameter larger than $0.5 \mathrm{~mm}$. 


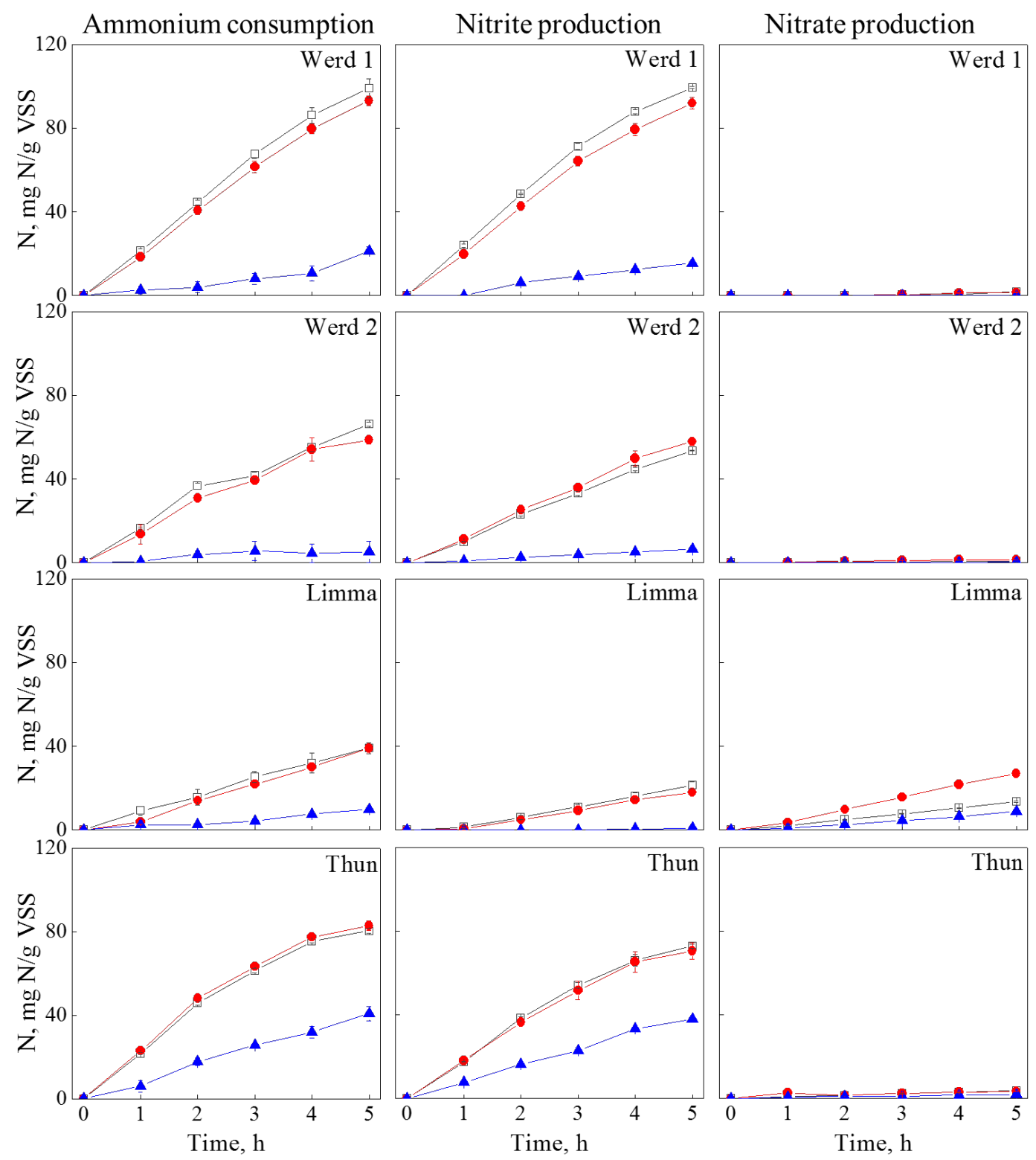

Fig 2. Biomass specific ammonium consumption as well as nitrite and nitrate production during aerobic batch experiments ( $\square$ Combined sludge, $\bullet$ Flocs, and $\Delta$ Granules). Error bars represent standard deviation at each time point for biological triplicates. 


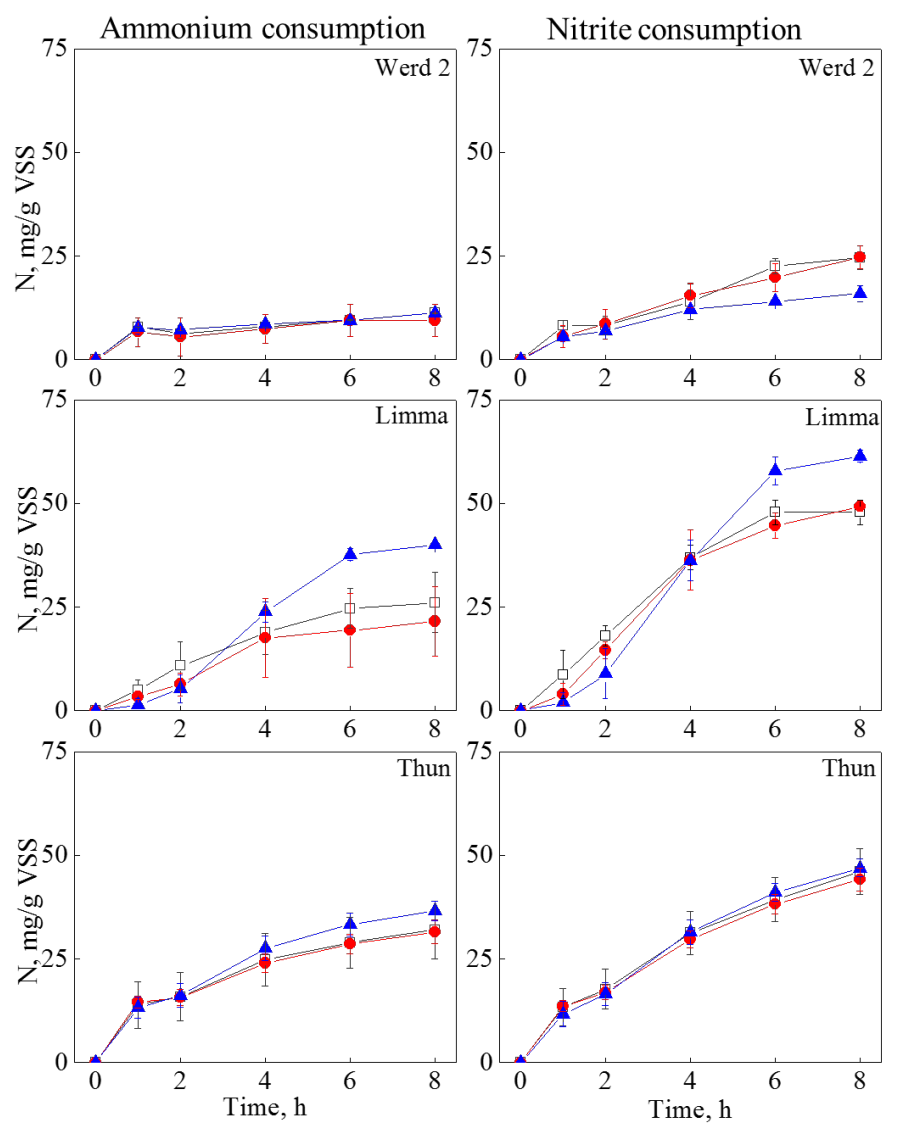

Fig. 3 Biomass specific ammonium and nitrite consumption during anoxic batch experiments, with nitrite as electron acceptor ( $\square$ Combined sludge, $\bullet$ Flocs, and Granules). Error bars represent standard deviation at each time point for biological duplicates. 


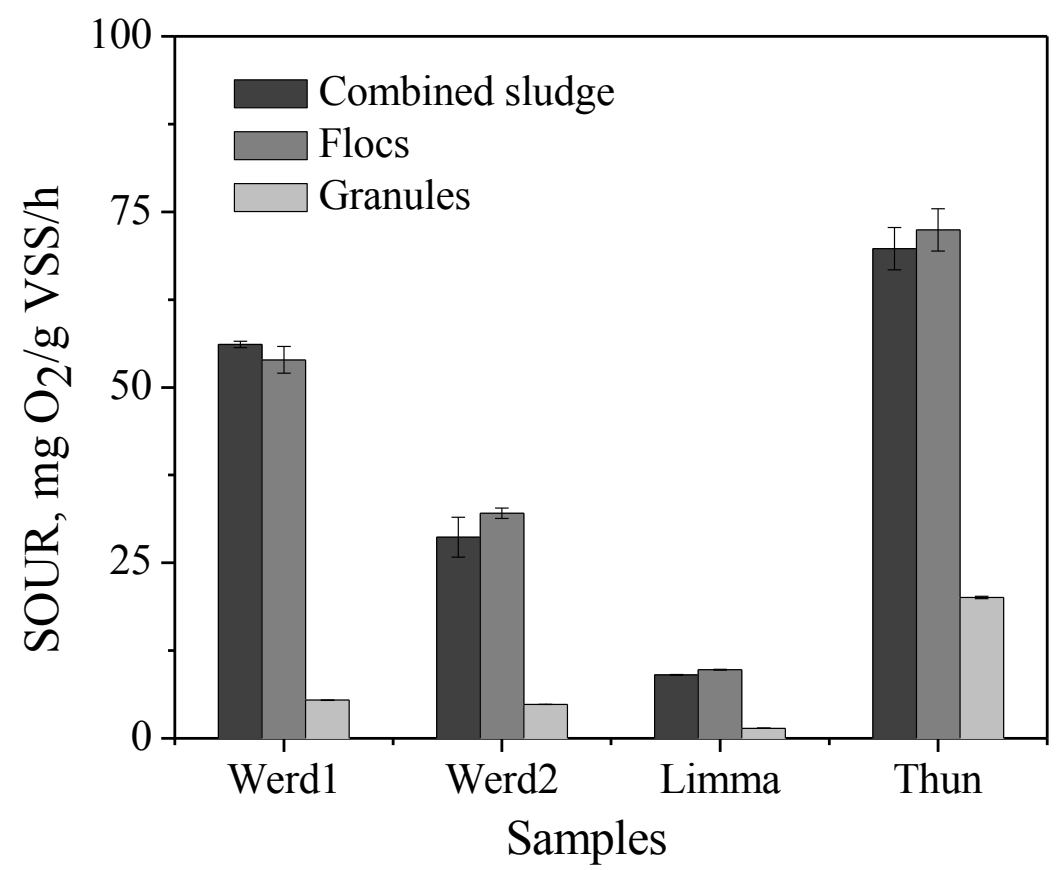

Fig. 4 Biomass specific oxygen uptake rates (SOUR) for combined, floccular $(<0.5 \mathrm{~mm})$, and granular $(>0.5 \mathrm{~mm})$ fractions from full-scale nitritation-anammox reactors 
Table 1 Overview of the three full-scale suspended growth combined nitritationanammox reactors investigated in this study. Operational conditions represent typical values for each reactor, per communications with system operators. All systems are in Switzerland.

\begin{tabular}{|c|c|c|c|}
\hline Parameters & Werdholzli WWTP & Limmattal WWTP & Thunersee WWTP \\
\hline Reactor type & SBR & $\begin{array}{l}\text { SBR, with } \\
\text { hydrocyclone* }\end{array}$ & $\begin{array}{l}\text { SBR, with } \\
\text { hydrocyclone* }\end{array}$ \\
\hline Volume, $\mathrm{m}^{3}$ & 1400 & 250 & 700 \\
\hline $\begin{array}{l}\text { Influent } \mathrm{NH}_{3}{ }^{+}-\mathrm{N} \text {, } \\
\mathrm{mg} \mathrm{N} / \mathrm{L}\end{array}$ & $650 \pm 50$ & 1100 & $1100 \pm 75$ \\
\hline $\begin{array}{l}\text { Nitrogen removal } \\
\text { rate, g N/(L d) }\end{array}$ & 0.9 & - & 0.3 \\
\hline $\begin{array}{l}\text { Effluent } \mathrm{NH}_{3}{ }^{+}-\mathrm{N} \text {, } \\
\text { mg N/L }\end{array}$ & $30 \pm 10$ & 70 & $155 \pm 130$ \\
\hline $\mathrm{pH}$ & $7.8 \pm 0.1$ & - & $7.85-8.0$ \\
\hline Temperature & $30 \pm 3$ & - & $15-35$ \\
\hline $\mathrm{DO}, \mathrm{mg} / \mathrm{L}$ & - & $0.2-0.3$ & $<0.4$ \\
\hline
\end{tabular}

*DEMON Process 
Table 2 Activity and abundance of Anammox and AOB in different reactors and biomass fractions. $\mathrm{C}=$ combined biomass (prior to sieving), $\mathrm{F}=$ floccular biomass with diameter less than $0.5 \mathrm{~mm}$, and $\mathrm{G}=$ granular biomass with diameter higher than $0.5 \mathrm{~mm}$. Activity measurements are based on aerobic and anoxic batch experiments, and abundance data is based on quantitative FISH measurements.

\begin{tabular}{|c|c|c|c|c|c|c|c|c|c|c|c|c|}
\hline \multirow{2}{*}{ Parameters } & \multicolumn{3}{|c|}{ Werd1 } & \multicolumn{3}{|c|}{ Werd2 } & \multicolumn{3}{|c|}{ Limma } & \multicolumn{3}{|c|}{ Thun } \\
\hline & $\mathrm{C}$ & $\mathrm{F}$ & $\mathrm{G}$ & $\mathrm{C}$ & $\mathrm{F}$ & $\mathrm{G}$ & $\mathrm{C}$ & $\mathrm{F}$ & $\mathrm{G}$ & $\mathrm{C}$ & $\mathrm{F}$ & $\mathrm{G}$ \\
\hline \multicolumn{13}{|l|}{ Sludge } \\
\hline Sludge sampling date & \multicolumn{3}{|c|}{ April 25, 2012} & \multicolumn{3}{|c|}{ October 05,2012} & \multicolumn{3}{|c|}{ May 8, 2012} & \multicolumn{3}{|c|}{ October 04, 2012} \\
\hline Collection facility & \multicolumn{3}{|c|}{ Werdholzli WWTP } & \multicolumn{3}{|c|}{ Werdholzli WWTP } & \multicolumn{3}{|c|}{ Limmattal WWTP } & \multicolumn{3}{|c|}{ Thunersee WWTP } \\
\hline $\begin{array}{l}\text { Volume weighted mean } \\
\text { aggregate diameter, } \mu \mathrm{m}\end{array}$ & $287 \pm 18$ & $284 \pm 17$ & $767 \pm 10$ & $298 \pm 17$ & $295 \pm 11$ & $703 \pm 20$ & $322 \pm 4$ & $250 \pm 2$ & $536 \pm 4$ & $217 \pm 10$ & $183 \pm 6$ & $592 \pm 6$ \\
\hline$\%$ of total VSS & - & 97.5 & 2.5 & - & 96.6 & 3.4 & - & 94.3 & 5.7 & - & 88.8 & 11.2 \\
\hline \multicolumn{13}{|l|}{ Aerobic test } \\
\hline $\begin{array}{l}\text { Rate of } \mathrm{NH}_{4}{ }^{+}-\mathrm{N} \\
\text { consumption, } \mathrm{mg} \\
\text { N/gVSS/day }\end{array}$ & $476 \pm 22$ & $448 \pm 11$ & $103 \pm 9$ & $318 \pm 5$ & $282 \pm 10$ & $25 \pm 25$ & $188 \pm 13$ & $188 \pm 5$ & $47 \pm 3$ & $386 \pm 5$ & $398 \pm 11$ & $196 \pm 17$ \\
\hline $\begin{array}{l}\text { Rate of } \mathrm{NO}_{2}^{-} \text {-N production } \\
\text { (net), } \mathrm{mg} \mathrm{N} / \mathrm{gVSS}^{*}{ }^{*}{ }^{*}\end{array}$ & $478 \pm 2$ & $442 \pm 13$ & $74 \pm 3$ & $258 \pm 1$ & $278 \pm 9$ & $31 \pm 2$ & $103 \pm 7$ & $87 \pm 5$ & $2 \pm 0$ & $350 \pm 5$ & $338 \pm 19$ & $183 \pm 0$ \\
\hline $\begin{array}{l}\text { Rate of } \mathrm{NO}_{3}^{-}-\mathrm{N} \text { production, } \\
\mathrm{mg} \mathrm{N} /(\mathrm{gVSS} \text { day })^{*}\end{array}$ & $8 \pm 0$ & $8 \pm 1$ & $5 \pm 0$ & $4 \pm 3$ & $7 \pm 0$ & $2 \pm 0$ & $65 \pm 1$ & $129 \pm 4$ & $43 \pm 1$ & $18 \pm 0$ & $17 \pm 1$ & $9 \pm 0$ \\
\hline NAR & $98.4 \%$ & $98.2 \%$ & $93.7 \%$ & $98.5 \%$ & $97.5 \%$ & $93.9 \%$ & $61.3 \%$ & $40.3 \%$ & $4.4 \%$ & $95.1 \%$ & $95.2 \%$ & $95.3 \%$ \\
\hline \multicolumn{13}{|l|}{ Anoxic test } \\
\hline $\begin{array}{l}\text { Rate of } \mathrm{NH}_{4}{ }^{+}-\mathrm{N} \\
\text { consumption, } \mathrm{mg} \\
\text { N/gVSS/day }\end{array}$ & - & - & - & $34 \pm 1$ & $28 \pm 11$ & $34 \pm 2$ & $78 \pm 22$ & $65 \pm 25$ & $120 \pm 1$ & $96 \pm 21$ & $95 \pm 9$ & $110 \pm 7$ \\
\hline $\begin{array}{l}\text { Rate of } \mathrm{NO}_{2}^{-}-\mathrm{N} \\
\text { consumption, } \mathrm{mg} \\
\mathrm{N} / \mathrm{gVSS} / \text { day }^{* *}\end{array}$ & - & - & - & $74 \pm 9$ & $74 \pm 8$ & $48 \pm 6$ & $144 \pm 9$ & $148 \pm 4$ & $184 \pm 4$ & $139 \pm 17$ & $133 \pm 8$ & $141 \pm 6$ \\
\hline
\end{tabular}




\begin{tabular}{|c|c|c|c|c|c|c|c|c|c|c|c|c|}
\hline $\begin{array}{l}\text { Ratio of } \mathrm{NH}_{4}^{+}-\mathrm{N} \text { and } \mathrm{NO}_{2}^{-}- \\
\mathrm{N} \text { consumption }\end{array}$ & - & - & - & 2.18 & 2.64 & 1.41 & 1.85 & 2.28 & 1.53 & 1.45 & 1.40 & 1.28 \\
\hline \multicolumn{13}{|l|}{ FISH quantification } \\
\hline AOB abundance $(\%)$ & $21 \pm 7$ & $34 \pm 8$ & $9 \pm 2$ & $20 \pm 2$ & $26 \pm 4$ & $4 \pm 1$ & $12 \pm 5$ & $15 \pm 3$ & $2 \pm 1$ & $19 \pm 6$ & $31 \pm 5$ & $4 \pm 3$ \\
\hline Anammox abundance (\%) & $11 \pm 4$ & $15 \pm 4$ & $26 \pm 7$ & $9 \pm 3$ & $2 \pm 1$ & $48 \pm 10$ & $25 \pm 2$ & $2 \pm 1$ & $42 \pm 9$ & $51 \pm 11$ & $24 \pm 3$ & $80 \pm 7$ \\
\hline $\begin{array}{l}\text { Ratio of Anammox/AOB } \\
\text { abundance }\end{array}$ & 0.52 & - & - & 0.45 & - & - & 2.08 & - & - & 2.68 & - & - \\
\hline
\end{tabular}

Aerobic activity experiments were performed in triplicate at $28{ }^{\circ} \mathrm{C}$.

** Anoxic activity experiments were performed in duplicate at $32{ }^{\circ} \mathrm{C}$.

Replicate data are presented +/- one standard deviation. 


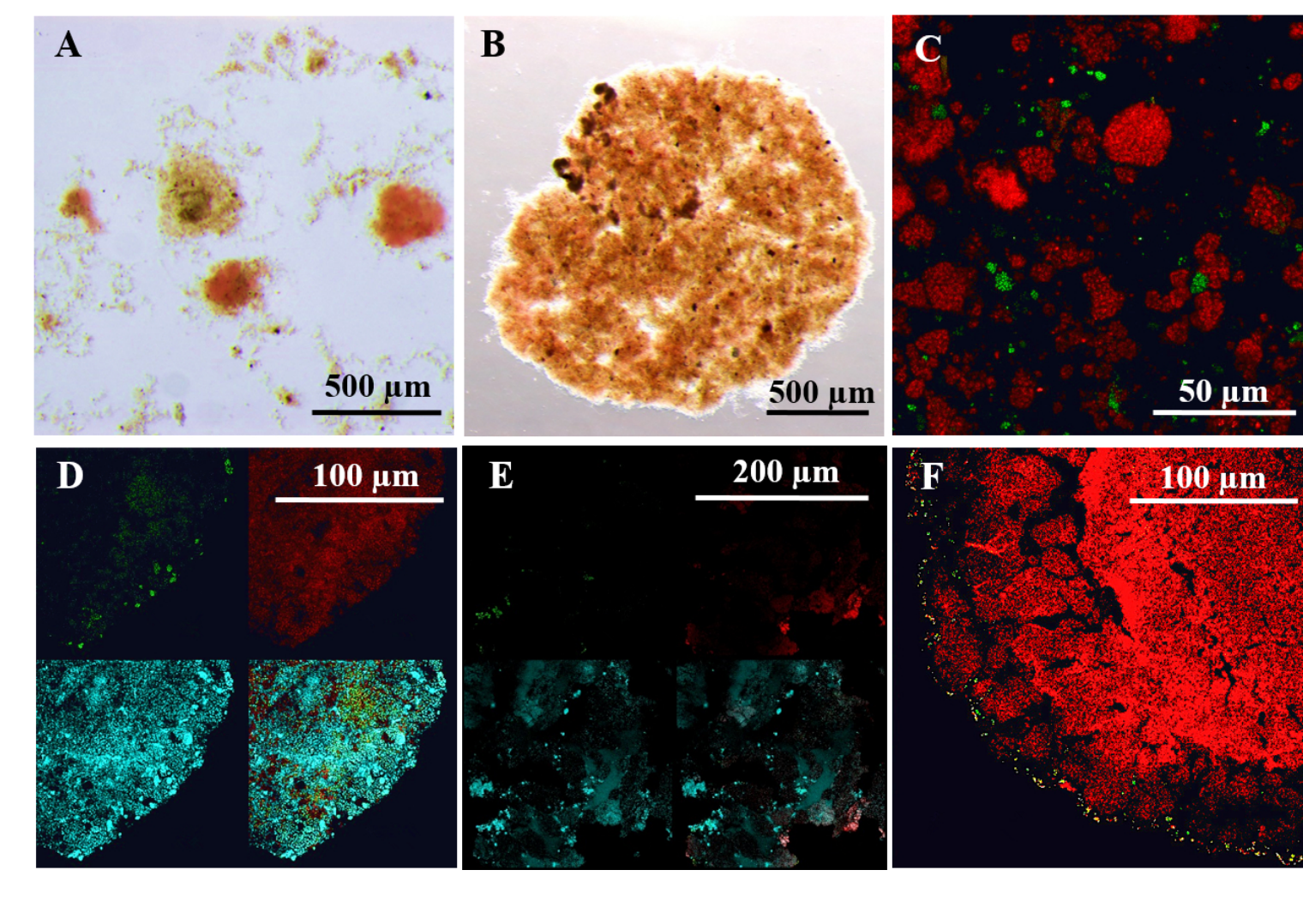

B
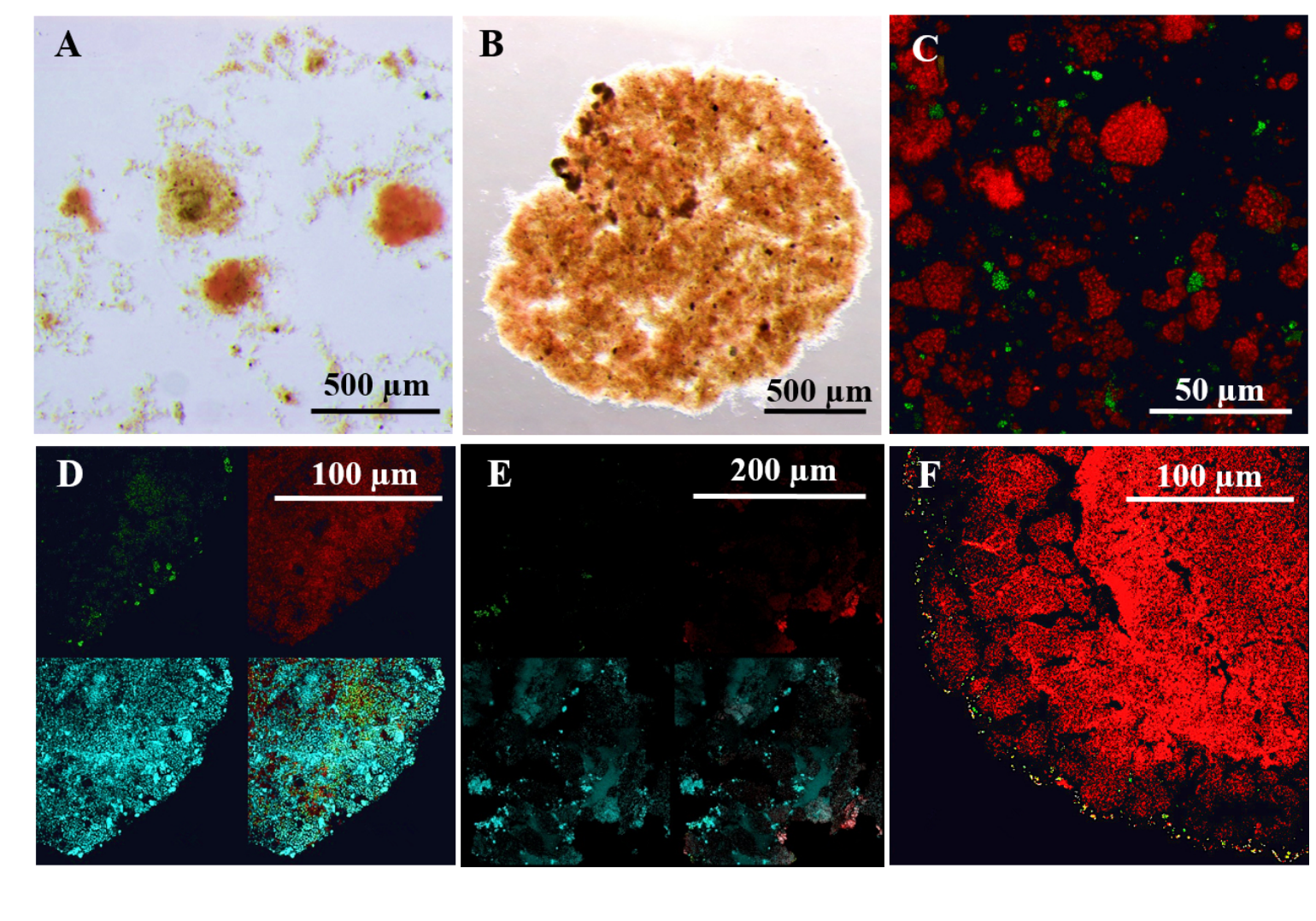

\section{Graphical Abstract (for review)}

